American J. of Engineering and Applied Sciences 4 (3): 413-424, 2011

ISSN 1941-7020

(C) 2014 Ibraheem and Gani, This open access article is distributed under a Creative Commons Attribution

(CC-BY) 3.0 license

\title{
Evaluation of Common Maintenance Methods for Flexible Pavements
}

\author{
Asma T. Ibraheem and Suda M. Gani \\ Department of Civil Engineering, College of Engineering, \\ Nahrain University, Baghdad, Iraq
}

\begin{abstract}
Problem statement: With the increasing use and awareness of pavement management systems and the growing emphasis on asset management of pavement infrastructure, it is important to strengthen the maintenance components of these systems and particularly the preventive maintenance component. Iraqi roads don't receive an effective and proper maintenance during their service life until they reach the state of major failure that requires rehabilitation. Roads in Iraq are being lost. Approach: In this study, a study of the status of maintenance methods for road pavements in Iraq with special reference to flexible pavements was presented. For this purpose, open and closed questionnaires were executed in Baghdad to investigate the status of road pavement maintenance in Iraq. Road maintenance offices as (Ministry of construction and Housing, State Corporation for Roads and Bridges, Amanat Baghdad, Project office,) were included in the questionnaire to arrive at the level of maintenance and techniques followed to maintain paved road in Iraq. Results: The interviews carried out reveal that maintenance in Iraq has secondary importance, apparently with no special budget allocated for such important works. In addition the maintenance methods and techniques followed do not comply the developments and modern techniques. Conclusion/Recommendations: Poor and miss-management of maintenance works and activities leading to delays and accumulation of failure in the highway network that require unusual expenditures to repair and maintain the accumulated damages. Shortages in resources allocated for maintenance works and this leads to the diversion of significant portion of the allocated fund for maintenance works toward purchasing of new, or additional equipment to be used for the construction of new roads. It is strongly recommended to design a planning system for management pavement maintenance of road network in Iraq and develop a particular failure criterion for roads in Iraq.
\end{abstract}

Key words: Flexible pavement, transportation engineering, state corporation, modern techniques, maintenance includes, road network

\section{INTRODUCTION}

The road agencies lending money for roads are concerned about this. Inadequate maintenance is the cause of the problem. Maintenance includes all activities needed to keep a country's road network operating indefinitely (Garber and Hole, 2009):

- Routine maintenance (restoring drainage, filling potholes and cracks, maintaining edges)

- Periodic maintenance (resealing, about every 5 years, to rejuvenate the surface)

- Rehabilitation (overlaying, about every 15 years, to restore smoothness and durability)

A road network is sustainable when it is in satisfactory condition and does not, as a whole, deteriorate over time. Individual roads do not remain Corresponding Author: Asma T. Ibraheem, Department of Civil Engineering, College of Engineering, Nahrain University, Baghdad, Iraq static paved roads go through a cycle of accumulating roughness, despite routine and periodic maintenance, until they are restored to their original smoothness by rehabilitation.

Since a network is made up of roads that individually are at all points in this maintenance cycle, the condition of the network as a whole does not change year by year. A sustainable road network is, therefore, one that is maintained. Inadequate maintenance is attributable to any of the following reasons:

- Money is not allocated (in sufficient amounts)

- Money is allocated but not spent

- Money is not spent efficiently

- Money is not spent effectively

In principle, the problem should not be hard to fix. All that is needed is a systematic and rational set of 
rules and tools to identify and plan maintenance tasks, a trained workforce with equipment to carry out the work and the money to pay for it. Experience reveals, however, that solving the road maintenance problem is considerably more resistant to solution than it appears. Waiting until after a failure occurs is not cost-effective or preventive maintenance. The effectiveness of a preventive maintenance treatment is directly related to the condition of the pavement. Conducting preventive maintenance activities on a sound pavement in good condition will be very effective in prolonging that pavement's service life. Conducting an inappropriate repair (either method or timing) can actually accelerate the rate of distress development. Preventive maintenance is generally planned and cyclical in nature. Its intent is to repair early pavement deterioration, delay pavement failures and reduce the need for corrective maintenance and service activities. Although this type of maintenance is not performed to improve the loadcarrying capacity of a pavement, it extends the pavement useful life and level of service. Often, preventive maintenance methods are designed to repair damage caused by the environment. Periodic renewal of the pavement surface can provide several benefits, including sealing the pavement surface, which prevents water from penetrating into the pavement structure and controlling the effects of oxidation, raveling and surface cracking. Environmental conditions remain fairly consistent over time, so the maximum time between preventive maintenance treatments should be based on time, rather than the amount of traffic on a roadway section.

Critical elements of a successful pavement preservation program are:

- $\quad$ Selecting the roadway

- Determining the cause of the problem

- Identifying and applying the correct treatment (s)

- Determining the correct time to do the needed work

- Observing performance

\section{MATERIALS AND METHODS}

Maintenance propellants: Undoubtedly, there are problems that necessitate maintenance as solutions to their effects and these problems are as given by Haggag (2009):

- Road safety problems, namely

- Shoulders erosion

- Growth of weeds on the shoulders and carrot centrism

- Blocking of water streams and this may cause road erosion during floods
- Damaged traffic signs, extension and warning signs

- Different potholes on the road surface

- Road planning

- Damaged bridges

- Damaged fences safety

Problems of optimal investment expended costs on the construction of the road: Improper understanding of material behavior prevents the efficient and correct usage of available materials and consequently, increases the construction and Maintenance costs and even unsuitable construction.

The maker of road construction decision hopes that the investment funds to be disbursed for their usefulness no doubt it was assumed that the road needed to strengthen the continuing work through its design, there are costs and benefits consist the elements of study of economic feasibility of the road, where costs of continuous maintenance over the life of the road fall within the total costs and it amounts assumed in the preparation of the study and therefore the road during the operational life must be efficiently contribute to reduce the costs and increase the benefits that comes through continuous maintenance and avoid the need for resurfacing or reconstruction of part or all of road including these caused by the additional cost.

Problems of additional Costs for road users: No doubt there is a strong correlation between the state of the road surface (such as roughness, Smoothness, potholes, rutting, ...) and the cost of vehicle operation (voc). The Studies show that leaving the surface of the road without treatments lead to a significant increase in the cost of operating the vehicle and the economic analysis for maintenance indicates that the high rate of investment return in the case of expedite by implementation of maintenance programs.

Expenditures on road developments: Good highway and road system in a country provides different benefits to the society. Improving the road and highway system will result in increasing benefits to the road users such as SCRB, 2005:

- Reduction in vehicle operational cost

- Saving in travel time, which means benefits in terms, of time cost of vehicle and in terms of time cost of the user

- Reduction in accident rates and their related costs

- Improved level of service and ease of driving

- Improved level of comfort to users 
Am. J. Engg. \& Applied Sci., 4 (3): 413-424, 2011

By the end of 1970 Iraq started a program for the development of road network. The program included the establishment of expressways network in the country. Hundreds of kms of expressways and highway were under construction each year during the above mentioned period. Funds were allocated annually to cover the new construction and development activities Ministry of Planning, 2008.

Comparison of highway maintenance expenditure: World Bank 2011 reported that the maintenance expenditure tended to represent a percentage of total highway expenditure. Such percentage differs from country to country and from period to period due to several factors, which may be economical, financial, technical. For example in the U.K in the early 1960s, maintenance expenditure represented around $60 \%$ of total roads expenditure.

By the early to mid 1970 this was reduced to an average of $40 \%$ and in the 1980s and early 1990s ran at around $50 \%$. The percentage in some countries is between $1-10 \%$, while this percentage is around 20 to $30 \%$ as an average for developing countries.

In some Arab countries in the region including Iraq, the percentage of maintenance expenditure to the total road expenditure is $7.5 \%$ for Saudi Arabia, 1.5\% Qatar, 2\% Iraq, 4\% Kuwait and 9\% for Oman, during 1970 s in the 1980s the percentage for Iraq is as mentioned in Table 1 Ministry of Planning, 2008.

According to the estimate of the World Bank (Ajam, 1999), the unit rate of the master maintenance activities are:

- $\quad$ Routine maintenance $\$ 200-\quad 1000 \mathrm{~km}^{-1}$

- Periodic maintenance $\$ 8000-10000 \mathrm{~km}^{-1}$

- Overlay $\$ 50000-75000 \mathrm{~km}^{-1}$

- Rehabilitation $\$ 120000-200000 \mathrm{~km}^{-1}$

The unit rate of $5 \mathrm{~cm}$ overlay for highways in Iraq varied from around ID $4 \mathrm{~m}^{-2}$ in 1990 to around ID 160 $\mathrm{m}^{-2}$ in 1995. Shoulder stabilizing cost around ID 1.2 $\mathrm{m}^{-2}$ in 1990 and it was ID $80 \mathrm{~m}^{-2}$ in 1995 . According to the rate of overlay in 1995. According to the rate of overlay in 1995, the estimated cost of overlay for 8 meter width of road should be ID 1.2 million $\mathrm{km}^{-1}$. On the same basis shoulder stabilizing should be ID 0.6 million $\mathrm{km}^{-1}$.

Common damages of roads in Iraq: SCRB, 2005 reported that the roads are designed according to different specifications owing to the differences in the environment, resources and the purpose.
Table 1: (\%) Maintenance to total road expenditure in Iraq, Ministry of Planning, 2008

\begin{tabular}{lr}
\hline Year & $(\%)$ \\
\hline 1985 & 15.6 \\
1986 & 2.1 \\
1987 & 5.0 \\
1988 & 10.4 \\
1989 & 5.0 \\
\hline
\end{tabular}

However, roads are more subject to damage due to change in friction and hitting powers between the vehicle's wheels and the surface of the road. Moreover, roads are exposed to nature factors, which play a damaging role, resulting from variation of temperature and humidity between day and night or from one season to another. Damage in the roads comes as results of one or more of the following reasons (Al-Zawiny, 2000):

- Natural and weather factors

- Mistakes in the design

- Mistakes in the implementation methods

- Failure in the quality control of materials

- Periodic maintenance negligence

- Road misuse because of vehicles with axle loads exceeding the allowed limits

It is worth mentioning that the statistics of bridges and roads general state, have proved that $74 \%$ of the damages in Iraqi roads, result from the excess of the axial loads, particularly the damage resulting from them, equals the axial loads above to power four (Al-Zubaydi, 1989).

The Status of maintenance in Iraq: Iraq has important and basic network of roads. The network includes expressways. The estimated funds invested to build the expressways portion of the network were 1.2 billion ID. The remaining portion is $23000 \mathrm{~km}$ of highways. The invested funds in this portion were 3.2 billion ID.

In order to keep the network in service during its useful life and to protect the invested funds used to build the network by prolonging the service life, preventing rapid deterioration and prolonging the period for the need of rehabilitation works, therefore the logic requires the start of building and developing an effective maintenance management system include the following requirements:

- The acceleration, which accompanied the implementation process of new roads not accompanied by the rise in maintenance programs comply with the size of investment and the period of implementation of this Large network of roads and streets characterized by the following features Ministry of planning, 2008 
- Multiple actors for roads and streets in terms of ministries or actors. Varying quality of implementation because of divergence in specifications adopted by those who carried out the road network

- Concentration in certain phases on quantity without giving importance for the quality of works, especially during the period of direct execution

- No constrain with design assumption for road in terms of axle loads where the road is designed depend on certain axle load, while allowing heavy loads to use the road without restrictions

- The existence of natural problems in the country, especially variations in temperature and the presence of hot and long season

- Failure of materials used in the mixture, where these materials not in accordance with standard specifications

- The absence of precise specifications fit the circumstances and regions of Iraq, especially during previous periods, but depends on the American or British specifications

- No constrain with road type in terms of use

- There is no proportion in the spacing of construction new roads and their maintenance; therefore the discrepancy increased significantly and maintenance allocations become not subject to monitoring as needed, but placed in the constrains and limitations such as decision of allocation it within the current budget

- The maintenance methods, which are used in Iraq are overdue and not convoyed the developments in maintenance techniques used in the world

- The maintenance techniques in Iraq are limitable, where resurfacing consider as the most maintenance method used more than others also overlays and reconstruction implemented when the roads being very poor

- The implementation of maintenance techniques is not accurate; also it is not satisfy the specifications

- The choice of maintenance method almost is random without executing any advance inspections or tests in order to assigning the damage types, severity and extent levels to choose the suitable maintenance method which depend upon the road condition

- Failure of materials which are used for road maintenance in tests though this fact these materials used
- There is no special fund for road maintenance separate from annually budget

- Absence of periodic and permanent maintenance for simple damages which appears in paved roads in right time and this lead to sever failure types occur in these roads

- Absence of preventive maintenance, this very necessary to preserve the roads in good condition continuously if implemented in suitable time

The study conducted by the Ministry of Planning, 2008 on the technical and economic evaluation for the roads maintenance in the country shown that in the country spent on every $1 \mathrm{~km}$ of road maintenance about $34 \%$, which spends in Jordan and $10.1 \%$, which spends in Saudi Arabia and $17.1 \%$, which spends in Syria and $11.1 \%$, which spends in Yemen.

Construction of road network cost 8 Billion ID and will cost about 15 Billion if reconstructed again. It is huge national treasure that received wide scale of carelessness. Studies carried out by the Ministry of Planning, 2008 indicated that, the funds allocated for the maintenance of highways in Iraq was around 14\% of the funds required according to the United Nation standards. Such standards based on roads constructed according to the best international standards and specifications and designed to carry known range of axle loads. Such level is not the actual and existing level of the road network.

The common causes for pavement distresses in Iraq: The distresses in asphalt pavement may be not appear at soon but after long period of time with using road and increasing traffic volume and loads or increasing ground water level that leads to reduce the carrying capacity of subgrade, these damages vary with road condition, traffic volume, loads and treatment at time to avoid these damages. To get a good maintenance for flexible surface of asphalt pavement necessary know the reasons beyond distresses occurrence. The most common reasons for failures in asphalt pavement are (Gani, 2008; Haggag, 2009):

- Weak design for road and unsuitability for increasing in traffic loads and number of vehicles or not use the right method in design and construction of old road pavements

- Remaining water on pavement surface reduces friction and increase the thickness of water layer and the potential for hydroplaning 
Am. J. Engg. \& Applied Sci., 4 (3): 413-424, 2011

- No suitable drainage channels found to facilitate water drainage or not clean these channels in addition to that the size and depth of channels unsuitable so the drainage channels not reach to the lower regions to drains water

- Inadequate cross slope, especially in the shear regions should be as $0.5 \%$, so the longitudinal for side channels should be more than the longitudinal slope for road

- The crown is lower than the limited value for road type where this value should be in the rage (1.5-2\%)

- Increasing the level of ground water table and road pavement pass through poor drainage regions

- The level of road pavement is lower than the level of adjacent ground this cause poor drainage conditions

- Leave the pavement without resurfacing for long period loads to entry of water cross cracks and holes to the base and other layers of road pavement

- Inadequate environmental and climate conditions during road construction

- Accumulation of clay materials on the surface of pavement without removing these materials

- Continuous precipitation of snow on pavement surface and stay without removal within short time

- No enough interest with application of standard specifications on construction and maintenance of road pavement also materials used for these purposes

- The level of shoulders lower than the level of pavement surface and raveling of shoulders soil, where the shoulder surface should be strong and plane with side slope between (1/30-1/40)

Investigating the status of maintenance of roads in Iraq: The role of fieldwork, concerns the level of maintenance of road pavements in Iraq and maintenance management system, also road pavement maintenance cost and maintenance type that wide spread in Iraq. The fieldwork is divided into two stages as follows:

- Preliminary stage includes personal interviews conducted by the researcher, in addition to open questionnaire process. The purpose of this stage is to collect the information and the opinion of engineers working in the Iraqi contracting companies. These information and the opinions are being about the concepts of maintenance and rehabilitation and type of maintenance, also the maintenance techniques for road pavement failures used in Iraq
- Secondary stage includes preparing closed questionnaire forms in the light of results obtained from personal interviews and open questionnaire process, distributing these forms among individuals of the research sample to answer the questions, collecting these forms, then analyzing the results statistically and discussing the result obtained from the statistical analysis

Personal interviews and open questionnaire process: In this stage the researcher conducted many of personal interviews with many of senior engineers were who have an experience in road maintenance projects. About 15 senior engineers were selected to conduct the interviews with them. Those senior engineers were from top project managers and engineers working in the contracting companies of ministry of construction and housing.

Open questionnaire forms which is shown in Appendix a used as a substitute for the interview. A group of questions have been prepared for the prepared for the personal interviews and open questionnaire process relating to the following issues (Gani, 2008):

- The ownership of roads in Iraq

- The road pavement maintenance activities in Iraq

- The maintenance type that wide spread in Iraq

- The difference between road maintenance and rehabilitation

- The maintenance management system in Iraq

- The cost of road maintenance in Iraq

- The most type of road pavement used in Iraq and why

- The most failure types in road pavement

- The most common maintenance techniques for road failures in Iraq

- The reasons for road pavement failures in Iraq

- The level of road pavement maintenance in Iraq

The results of interviews and open questionnaire process can be summarized as:

- Regarding the ownership of roads in Iraq, the results showed that:

- The responsibility of main roads inside Baghdad city back to Amana Baghdad

- The roads and streets within the residential areas are under the responsibility of the municipalities in those areas

- The ownership of highways in Baghdad attributed to the State Corporation for Roads and Bridges one of establishments of Ministry of Construction and Housing and the roads in 
other cities attributed to the State Corporation for Roads and Bridges in each city, also the internal roads under the responsibility of municipalities in these cities

- Regarding the road pavement maintenance activities in Iraq, the results showed that: The maintenance activities in Iraq are divided to:

- The maintenance of road surface

- Maintenance of shoulders and side slopes of the road

- Maintenance of adjacent areas and side butting

- Regarding the maintenance type that wide spread in Iraq, the results showed that: The type of maintenance in Iraq is emergency maintenance:

- Regarding the difference between maintenance and rehabilitation, the results showed that:

- There is great mix between concepts of road maintenance and rehabilitation, especially in contracting Iraqi companies

- The rehabilitation activities hold in Iraq more than maintenance activities

- The pavement maintenance aim to preserve pavement condition, safety and ride quality and therefore aid a pavement in achieving it is design life, but rehabilitation is the redressing of significant problems that are already part of the pavement section

- Regarding the maintenance management system in Iraq, the results showed that all the respondents confirmed the following:

- In Iraq there is no maintenance management system for roads

- The maintenance works include the important projects only depend upon the funds allocated by the ministry of finance and according the investment plan for each year

- Many roads in Iraq now need to maintain, but there is no enough fund because the above reasons

- Regarding the cost of road maintenance in Iraq, the results showed:

- All the respondents emphasized that the cost of road maintenance in Iraq increase continuously because of maintenance depend upon several factors such as labour cost, the cost of materials used in maintenance work, the cost of transport mechanisms and materials used in maintenance operations and the cost of the mechanisms and machinery. Since these factors in the continuing escalation, these fore the total cost of maintenance is also increase
- The cost of maintenance is increased because of absence of continuous and permanent treatment for simple failures occurs in road pavement

- $\quad$ Regarding the most type of road pavement used in Iraq and why? the results showed :

- All the respondents emphasized that the asphalt pavement is the wide spread in Iraq because of many reasons such as:

- Appropriateness of this kind of road for conditions in Iraq

- Abundance of raw materials used to construct the asphalt roads

- Abundance of stone quarries to the processing factories nearby asphalt materials rubble necessary

- Asphalt pavement advantage with easily and quickly construction and the exploitation of workers

- Lack of time, maintenance cost and ease of maintenance

- Regarding the most failure types in road pavement, the results showed:

- Most of the respondents emphasized that the cracks and potholes are the most failure types in asphalt roads and join failure and cracks the most failure types in concrete pavements

- Some of them believe that the rutting is the most failure type in asphalt pavement

- Regarding the most common maintenance techniques for road failures used in Iraq, the results showed:

- Most of the respondents confirmed that the resurfacing is the most common technique used to treatment the failures in road pavements in Iraq

- Some of them believe that there is special type of treatment for each type of failures

- Regarding the reasons for road pavement failures, the results showed:

- Most of the respondents confirmed that the failure in road pavements because of the used materials in construction the paved road in Iraq not satisfy the specification

- Some of them believe that the failure starts from mistakes in the design of mixing equation for asphalt and concrete pavements

- Some of them confirmed that the failures in road pavement as a result for the subgrade layer not satisfy the required conditions and not taken the weather conditions particularly 
temperature and ground water into consideration during the design

- Regarding the level of road pavement maintenance in Iraq the results showed:

- Most the respondent confirmed that the maintenance in Iraq is week

- Some of them believe that the maintenance of road pavement is acceptable

\section{RESULTS}

Closed questionnaire process: After completion of preliminary stage of field work, which is represented by personal interviews and open questionnaire process, the researcher employed the results obtained to conduct a closed questionnaire process as a second stage of field work according the following procedures:

- Designing closed questionnaire forms and the results of personal interviews and open questionnaire process

- Selecting the research sample and assigning the size of this sample

- Distributing the closed questionnaire forms among the individuals of sample to answer the questions, then collecting these forms and analyzing the results statistically

- Discussing the results obtained from the statistical analysis for the answers of respondents and deriving conclusions and recommendations

Designing the closed questionnaire forms: Closed questionnaire form has been designed following a simple method that enables all individuals of the sample to answer the question easily. The version of closed questionnaire form distributed among the questionnaire form includes the following articles:

- An introduction related to the researcher illustrating the objectives of the closed questionnaire process

- Personal information concerning the respondents (e.g., Work sector, academic degree, the specialist, the managerial position, experience years)

- An introduction related to the researcher illustrating the objectives of study and some of the main concepts of road pavement maintenance and its management, to make the answers more accurate

- The questions that consider the fundamental part of closed questionnaire form and these questions are designed based upon the results of preliminary stage of field work including personal interviews and open questionnaire process

Closed questionnaire form consists of 21 questions and these 21 issues were questioned:

- The importance degree of research subject for the road pavement maintenance project in Iraq

- The role of experience for the road maintenance team in accuracy of work

- The manner of road pavements serviceability in Iraq

- The degree of services that the Iraqi roads can produce

- The failure times of most roads in Iraq relative to design life

- The failure measurements for Iraqi paved roads

- The dependency of maintenance activities upon failure type in Iraq

- The most common reasons for failure of paved roads in Iraq

- Comply of design and construction methods of road pavements in Iraq with the methods used in the world.

- The level of maintenance methods used in Iraq

- The developments of maintenance techniques for paved road in Iraq with these occur in other countries now

- The level of maintenance activities for road shoulders, water drainage systems, lights and traffic signs

- The level of pavement maintenance works in Iraq compared with developed countries

- The best implementation method for road maintenance projects

- The influence of using preventive maintenance in Iraq upon state of paved roads

- The most common maintenance type used in Iraq

- The results of absence the continuous treatments for paved roads on increasing the maintenance cost

- The ability of financial treatment system to avoid more mistakes in paved roads in Iraq

- The results of lack the successful pavement management system in Iraq on accuracy of maintenance stages

- The effect of absence the pavement maintenance management system in Iraq on number of implemented maintenance projects

- The Level of maintenance decision making method followed in Iraq

The research sample: The important factor, that distinguishes the closed questionnaire process and its 
success, is the success of selecting the research sample. The selected research sample comprised in dividable working in the following engineering fields:

- Designing engineers, since some of the failures are related to the designers such as errors in road layers design

- Individuals working in the estimation and pricing field since those individuals limit the cost for each paragraph from maintenance work

- Maintenance engineers since those engineers maintain the failed road pavement when need these maintenance

- Field engineers working in construction or maintenance sites since those individuals are at contact with the cases of occurrence of error in mixture design or treatment selection or application

The researcher distributed (45) questionnaire forms, but only (40) forms had been received. So these (40) forms will be depended as basis for the statistical analysis as shown later in this chapter. Table 2 shows the number of respondents and their organization in which the closed questionnaire process was administrated.

Calculation of standard weights: After collection the questionnaire forms from the respondents, specified method was needed to analyze the answers statistically. Therefore the researcher adopted simplified method in which the statistical analysis of results includes two cases. The personal qualifications of the respondents are omitted in the first case and are considered in the other case. These personal qualifications especially experience years.

So to calculate the effect of these personal qualifications specified value is assumed for each personal factor using the following Eq. 1-3 as given by Mustafa (2001):

$\mathrm{SW}=\mathrm{F} 1 \times \mathrm{F} 2 \times \mathrm{F} 3$

The researcher decided to take two cases \{ case (A) and case (B) \} during assuming the factors instead of one case, in each case, the factors are changed by changing the assumed increment between the ranges as shown in Table 1. Therefore, each respondent will have two standard weights. For example, the first individual of respondents has (49) years working in engineering field, the degree of philosophy in engineering $(\mathrm{PhD})$, between (5-15) experience years in working on sites and less than (5) experience years in estimation and pricing, between (5-15) experience years in road maintenance works and more than (15) experience years as road designer, therefore, the standard weights are calculated by using the factors in Table 3 as shown, also more description of research sample is shown in Table 4.

\section{Case (A):}

$\mathrm{SW}=\{(49 / 100)+1\} \times 2.00 \times 2.50 \times 1.75 \times 2.00 \times$

$2.25=58.67$

Case (B):

$\mathrm{SW}=\{(49 / 100)+1\} \times 1.20 \times 2.25 \times 1.75 \times 1.75$
$\times 1.75=26.40$

\section{DISCUSSION}

Analysis method of closed questionnaire results: Analysis of the results depended upon calculating the number of frequencies for the answers and the weight average for the answers to identify the prevailing opinions of the respondents by adopting the following steps:

- Most of the questions comprised four choices as shown in Appendix A, since the respondent answers on one of these choices. The choices were as follows:

- Excellent Good Acceptable Poor

- Very important Little important Not important - Yes No

- The first step of analysis begins with identifying the number of frequencies for each one of the four choices without considering the effect of personal qualifications firstly and with considering the effect of personal qualifications secondly

- To calculate the weight average for the answers of the respondents, a weight value is assumed for each choice based upon a number of previously accomplished researches. This value represents the mid-range of assumed interval for each choice of the answer, as shown in Table 5

- To calculate the weighted average, using the following Eq. 4:

Table 2: Number of respondents closed questionnaire process and their organizations

\begin{tabular}{lr}
\hline Organization & $\begin{array}{c}\text { Number of } \\
\text { respondents }\end{array}$ \\
\hline Ministry of construction and Housing & 7 \\
Amanat Baghdad & 5 \\
Amanat Baghdad\Project Office & 7 \\
National center for Laboratories & 6 \\
State corporation for road and bridges & \\
Ministry of construction and Housing & 9 \\
Hammorabi Contracting Company & \\
Ministry of construction and Housing & 6 \\
Total & 40 \\
\hline
\end{tabular}


Am. J. Engg. \& Applied Sci., 4 (3): 413-424, 2011

Table 3: Proposed standard weights for personal qualification of the respondents

\begin{tabular}{|c|c|c|c|c|}
\hline $\begin{array}{l}\text { Personal qualifications } \\
\text { of the sample }\end{array}$ & \multicolumn{2}{|l|}{ Data description } & $\begin{array}{l}\text { Standard weight } \\
\text { Case (A) }\end{array}$ & Case (B) \\
\hline \multicolumn{5}{|l|}{ Experience years since the respondent } \\
\hline Worked in engineering field generally $(\mathrm{F} 1)$ & \multicolumn{2}{|l|}{ Practice Years } & {$\left[\frac{\text { practice year }}{100}+1\right]$} & {$\left[\frac{\text { practice year }}{100}+1\right]$} \\
\hline \multirow[t]{3}{*}{ Academic degree (F2) } & \multirow{2}{*}{\multicolumn{2}{|c|}{$\begin{array}{l}\text { B.Sc. } \\
\text { M.Sc. }\end{array}$}} & $* 1.00$ & $* 1.00$ \\
\hline & & & $* 1.50$ & $* 1.25$ \\
\hline & \multicolumn{2}{|l|}{ Ph.D. } & $* 2.00$ & $* 1.50$ \\
\hline \multicolumn{5}{|l|}{ Experience years in specified } \\
\hline \multirow[t]{3}{*}{ Field of road engineering $(\mathrm{F} 3)$} & \multirow[t]{3}{*}{ Working in sites } & $<5$ years & $* 2.00$ & $* 2.00$ \\
\hline & & $5-15$ years & $* 2.50$ & $* 2.25$ \\
\hline & & $>15$ years & $* 3.00$ & $* 2.50$ \\
\hline \multirow[t]{3}{*}{ Working in estimation and pricing } & $<5$ years & $* 1.75$ & $* 1.75$ & \\
\hline & $5-15$ years & $* 2.25$ & $* 2.00$ & \\
\hline & $>15$ years & $* 2.75$ & $* 2.25$ & \\
\hline \multirow[t]{6}{*}{ Working in road maintenance } & \multirow[t]{3}{*}{$<5$ years } & $* 1.50$ & $* 1.50$ & \\
\hline & & $5-15$ years & $* 2.00$ & $* 1.75$ \\
\hline & & $>15$ years & $* 2.50$ & $* 2.00$ \\
\hline & \multirow{3}{*}{ Working in design } & $<5$ years & $* 1.25$ & $* 1.25$ \\
\hline & & $5-15$ years & *1.75 & $* 1.50$ \\
\hline & & $>15$ years & $* 2.25$ & $* 1.75$ \\
\hline
\end{tabular}

Table 4: Description of the personal qualification of the respondents

\begin{tabular}{|c|c|c|c|c|c|c|c|c|c|}
\hline $\begin{array}{l}\text { Experience year in } \\
\text { Work } \\
\text { sector }\end{array}$ & $\begin{array}{l}\text { Engineering } \\
\text { field }\end{array}$ & $\begin{array}{l}\text { Standard } \\
\text { academic } \\
\text { degree }\end{array}$ & $\begin{array}{l}\text { Experience years } \\
\text { engineer }\end{array}$ & Sites & $\begin{array}{l}\text { Estimation } \\
\text { and pricing }\end{array}$ & $\begin{array}{l}\text { Weight } \\
\text { Maintenance }\end{array}$ & Design & Case A & Case B \\
\hline State & Civil & Ph.D. & 49 & $5-15$ & $>5$ & $5-15$ & $>15$ & 58.670 & 26.400 \\
\hline State & Civil & B.Sc. & 15 & $5-15$ & $5-15$ &.- &.- & 11.320 & 7.760 \\
\hline State & Civil & B.Sc. & 20 & $5-15$ & $<5$ &.- & $\ldots$ & 9.190 & 7.090 \\
\hline State & Civil & B.Sc. & 25 & $>15$ & $5-15$ & $5-15$ & $5-15$ & 15.840 & 10.940 \\
\hline Private & Civil & M.Sc. & 30 & $>15$ & $5-15$ & $<5$ & $<51$ & 24.680 & 15.230 \\
\hline State & Civil & Ph.D. & 40 & $5-15$ & $<5$ & $5-15$ & $5-15$ & 30.620 & 18.090 \\
\hline State & Civil & Ph.D. & 35 & $>15$ & $5-15$ &.- & -- & 18.220 & 10.120 \\
\hline State & Civil & B.Sc. & 20 & $>15$ & $5-15$ &.- & $\ldots$ & 14.120 & 9.000 \\
\hline Private & Civil & B.Sc. & 14 &.- &.- & $5-15$ & $5-15$ & 3.990 & 2.990 \\
\hline State & Civil & B.Sc. & 22 & $<5$ & - - - & $-\ldots$ & $-\ldots$ & 5.490 & 4.270 \\
\hline State & Civil & B.Sc.' & 18 & $5-15$ &.- &.- & $\ldots$ & 3.680 & 3.320 \\
\hline State & Civil & B.Sc. & 24 & $5-15$ & $<5$ & -- &.- & 8.140 & 6.780 \\
\hline State & Civil & B.Sc. & 19 & -- & $<5$ & -- &.- & 7.800 & 6.500 \\
\hline State & Civil & B.Sc. & 17 & - - - &.- & $<5$ & $<5$ & 4.390 & 3.940 \\
\hline State & Civil & Ph.D. & 43 & - - - & - - - & $<5$ & $<5$ & 24.130 & 12.660 \\
\hline State & Civil & B.Sc. & 32 & $<5$ &.- &.- &.- & 3.960 & 3.300 \\
\hline State & Civil & B.Sc. & 29 & $<5$ & $<5$ & $<5$ & $<5$ & 10.580 & 9.520 \\
\hline State & Civil & M.Sc. & 15 & $\ldots$ & $<5$ & $5-15$ & $5-15$ & 7.540 & 5.500 \\
\hline State & Civil & B.Sc. & 17 & $-\ldots$ & -- & -- & -- & 3.510 & 2.920 \\
\hline State & Civil & B.Sc. & 12 & -- &.- & $<5$ & $<5$ & 4.200 & 3.780 \\
\hline State & Civil & M.Sc. & 16 & $<5$ & - . & $<5$ & $\ldots$ & 6.960 & 4.350 \\
\hline State & Civil & B.Sc. & 5 & $5-15$ & $<5$ &.- & & 1.310 & 1.310 \\
\hline Private & Civil & B.Sc. & 7 & $5-15$ & $<5$ & $5-15$ & $5-15$ & 4.280 & 3.740 \\
\hline State & Civil & B.Sc. & 12 & $<5$ & - - & $<5$ & - - - & 4.200 & 3.780 \\
\hline State & Civil & B.Sc. & 12 & - - - & - - - & $<5$ & $\ldots$ & 13.780 & 10.330 \\
\hline State & Civil & M.Sc. & 5 & $>15$ & $<5$ & $<5$ & $\ldots$ & 3.150 & 3.150 \\
\hline State & Civil & B.Sc. & 10 & $5-15$ & $<5$ & $<5$ & $\ldots$ & 3.850 & 3.370 \\
\hline State & Civil & B.Sc. & 23 & $5-15$ &.- & $<5$ & $-\ldots$ & 9.680 & 6.920 \\
\hline State & Civil & Ph.D. & 18 & $5-15$ & $5-15$ & $<5$ & $<5$ & 4.430 & 3.980 \\
\hline State & Civil & B.Sc. & 9 & $<5$ & - - - & $<5$ & $\ldots$ & 3.150 & 3.150 \\
\hline State & Civil & B.Sc. & 10 & $>15$ & $\ldots$ & $5-15$ & $\ldots$ & 18.720 & 11.700 \\
\hline State & Civil & B.Sc. & 5 & $5-15$ & $5-15$ & $<5$ & $\ldots$ & 9.250 & 8.330 \\
\hline Private & Civil & B.Sc. & 19 & $>15$ & - - - & $>15$ & 10.89 & 5.620 & 6.350 \\
\hline State & Civil & Ph.D. & 13 & $5-15$ &.- & $5-15$ & 23.21 & 7.890 & 4.050 \\
\hline State & Civil & B.Sc. & 20 & $5-15$ & - - - & $5-15$ & $\ldots$ & 10.890 & 14.740 \\
\hline \multirow[t]{5}{*}{ State } & Civil & B.Sc. & 7 & $5-15$ & $5-15$ & $>15$ & - - - & 6.350 & 3.640 \\
\hline & & & 17 & & -- & $5-15$ & $>15$ & & 23.210 \\
\hline & & & 21 & & -- & - - - & $5-15$ & & 4.050 \\
\hline & & & 31 & & $5-15$ & $<5$ & $<5$ & & \\
\hline & & & 8 & &.- & $<5$ & -- & & \\
\hline
\end{tabular}


Weighted $_{\text {Average }(\mathrm{WA})=}$

$\sum^{\text {(Number of frequencies }}$

$\Sigma_{* \text { weightedvaluefor the particular choice) }}$

\section{Total number of the answers}

The last step is evaluating of obtained results by comparing them with assumed intervals.

Regarding the question that includes two choices (yes) and (No), the analysis depends upon calculating of the frequency percentages for the two choices only.

It is concluded from the results in Table 6 that there is almost negligible difference between the weight average without considering the effect of personal qualifications and the weighted average with considering the effect of personal qualifications and the weighted average with considering the effect of personal. Also, there is almost negligible difference between the results of two cases (A and $\mathrm{B}$ ), which consider the effect of personal qualifications, in spite of changing the standard weights of respondents because of changing the assumed factors. Figure 1-6 show the percentage of respondents for questions $(8,9,11,14,15$ and 20).

Table 5: The weighted values for answers

\begin{tabular}{lll}
\hline Type of answer & Interval & Weighted value \\
\hline Excellent & $0-25$ & 12.5 \\
Good & $25-50$ & 37.5 \\
Acceptable & $50-75$ & 62.5 \\
Poor & $75-100$ & 87.5 \\
\hline
\end{tabular}

Table 6: Final results of closed questionnaire analysis

\begin{tabular}{|c|c|c|c|c|c|c|c|}
\hline \multirow[b]{2}{*}{ Question } & \multirow{2}{*}{$\begin{array}{l}\text { AW without } \\
\text { personal } \\
\text { qualifications }\end{array}$} & \multicolumn{4}{|c|}{ AW with personal qualifications } & & \multirow[b]{2}{*}{ Final results } \\
\hline & & Case A & & Case B & & & \\
\hline $\begin{array}{l}\text { 1- What is the importance degree of } \\
\text { research subject in studying the state of } \\
\text { paved road maintenance in Iraq? }\end{array}$ & 80.070 & 78.95 & & 79.73 & & & Very important \\
\hline $\begin{array}{l}\text { 2- Does the experience of road maintenance } \\
\text { team play an important role in work accuracy? }\end{array}$ & 77.160 & 79.03 & & 78.93 & & & Very important \\
\hline $\begin{array}{l}\text { 3- What is your opinion in road pavement } \\
\text { serviceability in Iraq? }\end{array}$ & 78.750 & 80.37 & & 79.16 & & & Poor \\
\hline 4-Are the most of Iraq roads incapable & Yes & No & Yes & No & Yes & No & \\
\hline of serving the user completely? & 92.500 & 7.50 & 93.01 & 6.99 & 92.98 & 7.02 & \\
\hline $\begin{array}{l}\text { 5- Are the most roads in Iraq failed before } \\
\text { end of its design life? }\end{array}$ & 95.000 & 5.00 & 96.19 & 3.81 & 95.93 & 4.07 & \\
\hline $\begin{array}{l}\text { 6- Are there certain measurements to } \\
\text { sign failures of road pavements in Iraq? }\end{array}$ & 100.000 & 0.00 & 100.00 & 0.00 & 100.00 & 0.00 & \\
\hline $\begin{array}{l}\text { 7- Are the maintenance activities for } \\
\text { paved roads depend upon failure type? }\end{array}$ & 37.500 & 62.50 & 33.51 & 66.49 & 35.84 & 64.16 & \\
\hline $\begin{array}{l}\text { 8- Is the failure of road pavements in Iraq } \\
\text { result from : }\end{array}$ & & & & & & & \\
\hline a- Mistakes in mixture design. & 82.500 & 17.50 & 79.86 & 2.14 & 80.01 & 19.99 & \\
\hline $\begin{array}{l}\text { b- The material used not satisfies } \\
\text { the required specifications. }\end{array}$ & 85.000 & 15.00 & 87.13 & 12.87 & 79.99 & 20.01 & \\
\hline $\begin{array}{l}\text { c- The absence of enough } \\
\text { accuracy for each part of road construction } \\
\text { project from design to finish. }\end{array}$ & 97.500 & 2.50 & 94.09 & 5.91 & 96.82 & 3.18 & \\
\hline $\begin{array}{l}\text { 9- Are the design and construction methods } \\
\text { of road pavements used in Iraq } \\
\text { accordant with these used in the world? }\end{array}$ & 20.000 & 80.00 & 20.86 & 79.14 & 16.6 & 83.40 & \\
\hline $\begin{array}{l}10-\text { What is your opinion in maintenance } \\
\text { methods used in Iraq? }\end{array}$ & 77.140 & & 79.49 & & 78.74 & & Poor \\
\hline $\begin{array}{l}\text { 11- Are the maintenance techniques for } \\
\text { paved roads used in Iraq comply the }\end{array}$ & 7.500 & 92.50 & 6.54 & 93.46 & 5.81 & 94.19 & \\
\hline $\begin{array}{l}\text { developments occurring in other countries now? } \\
12 \text { - What is your opinion in maintenance } \\
\text { activities for road shoulders, water drainage }\end{array}$ & 52.990 & & 52.60 & & 53.00 & & Acceptable \\
\hline $\begin{array}{l}\text { systems, lights and traffic signs in Iraq? } \\
13 \text { - What is your opinion in the level of } \\
\text { pavement maintenance works in Iraq } \\
\text { compared with developed countries? }\end{array}$ & 86.080 & & 85.89 & & 85.96 & & Poor \\
\hline 14- Is the direct implementation for maintenance & 35.000 & 65.00 & 39.97 & 60.03 & 31.95 & 68.05 & \\
\hline $\begin{array}{l}\text { 15- Is the using of preventive maintenance in Iraq } \\
\text { projects by office better than implementation by contractor? } \\
\text { help in remaining roads in good state continuously? }\end{array}$ & 92.500 & 7.50 & 88.51 & 11.49 & 90.43 & 9.57 & \\
\hline $\begin{array}{l}16-\text { Is the emergency maintenance wide spread in } \\
\text { Iraq more than other maintenance types? }\end{array}$ & 95.000 & 5.00 & 97.77 & 2.23 & 93.33 & 6.67 & \\
\hline $\begin{array}{l}\text { 17- Is the absence of continuous treatments for } \\
\text { simple failure in paved roads in Iraq increase the } \\
\text { cost of maintenance greatly? }\end{array}$ & 80.000 & 20.00 & 82.23 & 17.77 & 79.89 & 20.11 & \\
\hline $\begin{array}{l}\text { 18-Are the system of financial treatments used in } \\
\text { Iraq enough to avoid more mistakes } \\
\text { in constructed paved roads? }\end{array}$ & 17.500 & 82.50 & 16.89 & 83.11 & 22.11 & 77.89 & \\
\hline 19- Is the lack of successful pavement management & 100.000 & 0.00 & 100.00 & 0.00 & 100.00 & 0.00 & \\
\hline
\end{tabular}


Am. J. Engg. \& Applied Sci., 4 (3): 413-424, 2011

Table 6: Continuous

system in Iraq makes the maintenance stages inaccurate?

20- Is the absence of pavement maintenance

87.5

management system in Iraq limits the maintenance

$12.5-89.00$

1.00

works by important projects only?

21- What is your opinion in the way of

maintenance decision making in Iraq?

16- Is the emergency maintenance wide sprea

54.0

12.5

89.00

85.39

14.61

$\mathrm{d}$ in Iraq more than other maintenance types?

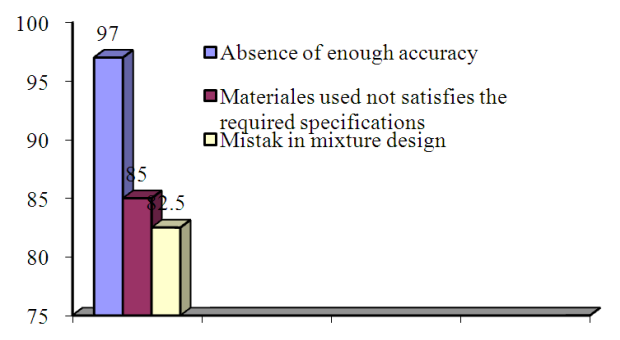

Fig. 1: Percentage of respondents for question (8)

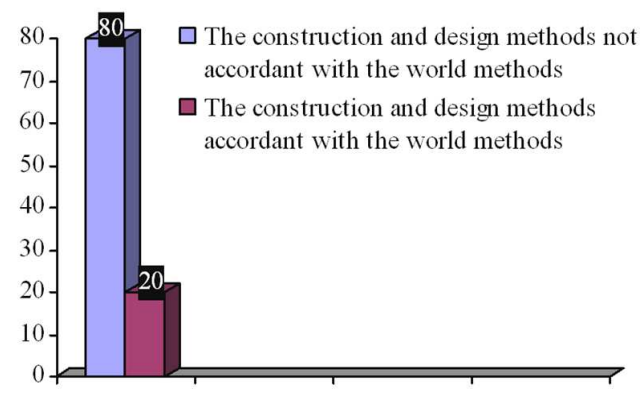

Fig. 2: Percentage of respondents for question (9)

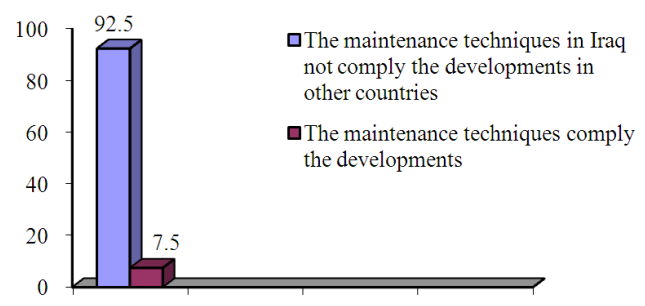

Fig. 3: Percentage of respondents for question (11)

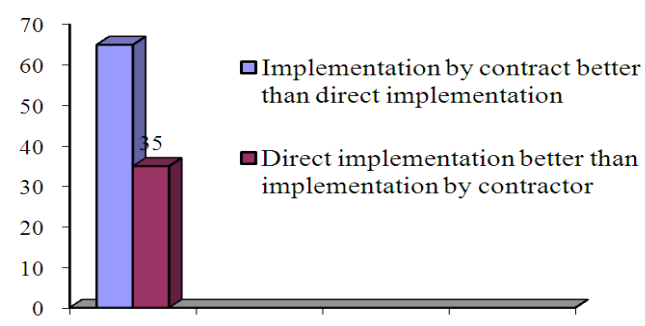

Fig. 4: Percentage of respondents for question (14)

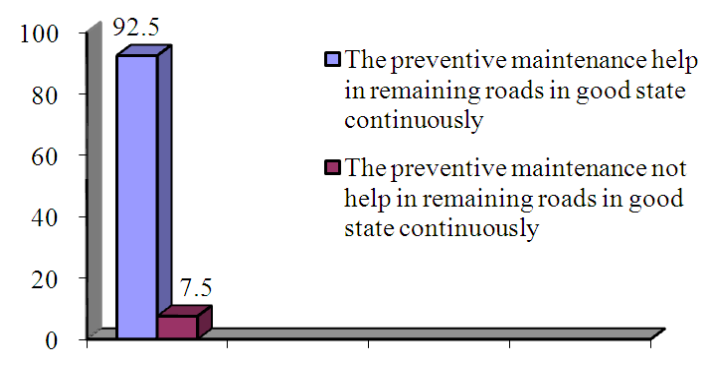

Fig. 5: Percentage of respondents for question (15)

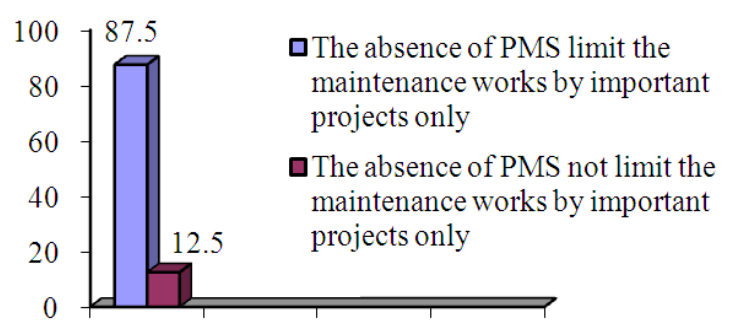

Fig. 6: Percentage of respondents for question (20)

\section{CONCLUSION}

The conclusions drawn from this study can be summarized as follows:

- Iraqi Roads don't receive an effective and proper maintenance during their service life until they reach the state of major failure that requires rehabilitation

- Preventive maintenance is excluded from the maintenance policy adopted by Iraqi road authorities

- Despite the proper control and effects required for maintenance, which is considered as a dynamic process, there is a lack of and shortage in qualified maintenance engineers working in road directorate in each governorate

- Lack of control regarding the load limit carried by vehicles and lack of weighing stations encouraging truck drivers to overload their trucks more than the permitted loads. If such case and conditions 
continue, the maintenance system will fail to achieve its objective, also great damages and losses in resources including investments will occur

- Machines and equipment allocated for maintenance works are not enough and not capable to perform the required jobs. In addition there is a lack of and shortage in the required number of equipment in repair workshops, also there is a severe shortage in the required spare parts for these repair shops

- Shortage of training activities and lack of information gathering about practices and experience of other countries regarding both of managerial and technical matters of highway maintenance

- Poor and miss-management of maintenance works and activities leading to delays and accumulation of failure in the highway network that require unusual expenditures to repair and maintain the accumulated damages

- Shortages in resources allocated for maintenance works and this leads to the diversion of significant portion of the allocated fund for maintenance works toward purchasing of new, or additional equipment to be used for the construction of new roads

- Modeling pavement maintenance management system for road network in Iraq is required

- It is strongly recommended to design a planning system for management pavement maintenance of road network in Iraq and develop a particular failure criterion for roads in Iraq

\section{REFERENCES}

Ajam, H.K.H., 1999. Development of an expert system to investigate the problems of failure in flexible pavement. M.Sc. Thesis, Department of Building and Construction, University of Technolgy.

Al-Zubaydi, M.M.A., 1989. Maintenance management system for express-way No. (1). M.Sc. Thesis, Department of Building and Construction, University of Technology.

Al-Zawiny, F.M.S., 2000. Modeling of transportation management for asphalt concrete pavement. M.Sc. Thesis, College of Engineering, Baghdad University, Baghdad, Iraq.

Gani, S.M., 2008. Evaluation of common maintenance methods for road pavements in Iraq. M.Sc. Thesis, Nahrain University, College of Engineering, Baghdad, Iraq.

Garber, N.J. and L.A. Hoel, 2009. Traffic and Highway Engineering. 4th Edn., Cengage Learning, Toronto, ON., ISBN: 0495082503, pp: 1230.

Haggag, M.Y., 2009. Cost analysis of a system involving common-cause failures and preventive maintenance. J. Math. Stat., 5: 305-310. DOI: 10.3844/jmssp.2009.305.310

Mustafa, H.H., 2001. Assessment of work study techniques in construction field in Iraq. M.Sc. Thesis, Department of Civil Engineering, College of Engineering, Baghdad University. 